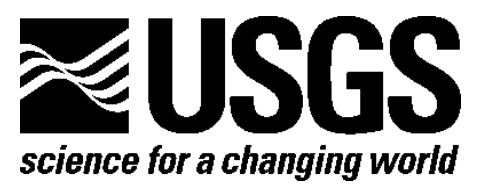

\title{
Surficial Geologic Map of the Red Rock Lakes Area, Southwest Montana
}

By Kenneth L. Pierce, Tara L. Chesley-Preston, and Richard L. Sojda

Pamphlet to accompany

Open-File Report 2014-1157

U.S. Department of the Interior

U.S. Geological Survey 


\section{U.S. Department of the Interior \\ SALLY JEWELL, Secretary}

U.S. Geological Survey
Suzette M. Kimball, Acting Director

U.S. Geological Survey, Reston, Virginia: 2014

For more information on the USGS—-the Federal source for science about the Earth, its natural and living resources, natural hazards, and the environment-visit http://www.usgs.gov or call 1-888-ASK-USGS

For an overview of USGS information products, including maps, imagery, and publications, visit $h$ ttp://www.usgs.gov/pubprod

To order this and other USGS information products, visit $h$ ttp://store.usgs.gov

Any use of trade, firm, or product names is for descriptive purposes only and does not imply endorsement by the U.S. Government.

Although this information product, for the most part, is in the public domain, it also may contain copyrighted materials as noted in the text. Permission to reproduce copyrighted items must be secured from the copyright owner.

Suggested citation:

Pierce, K.L., Chesley-Preston, T.L., and Sojda, R.L., 2014, Surficial geologic map of the Red Rock Lakes area, southwest Montana: U.S. Geological Survey Open-File Report 2014-1157, 22 p., scale 1:24,000, http://dx.doi.org/10.3133/ofr20141157.

ISSN 2331-1258 (online) 


\section{Contents}

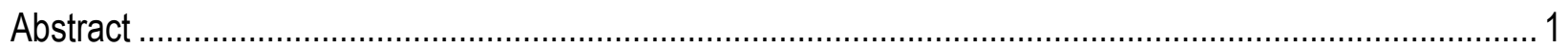

Surficial Geologic History of the Red Rock Lakes Area ..................................................................... 1

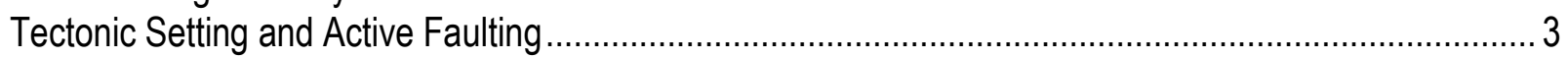

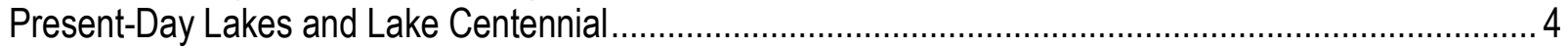

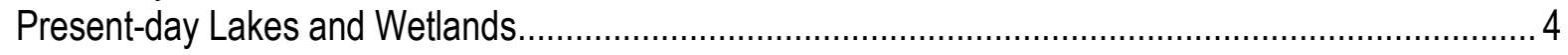

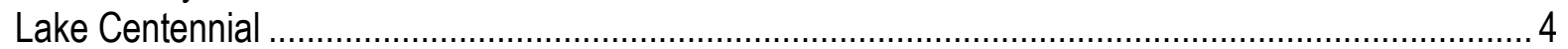

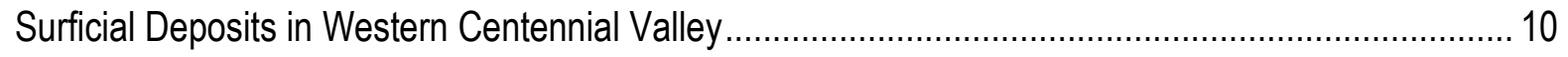

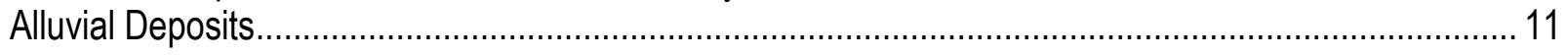

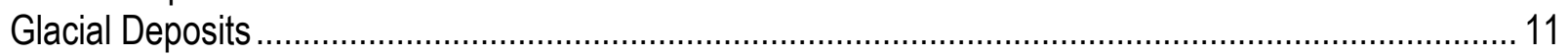

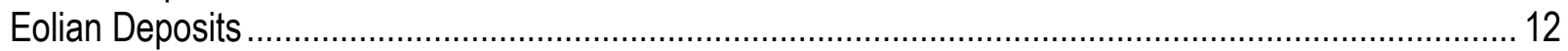

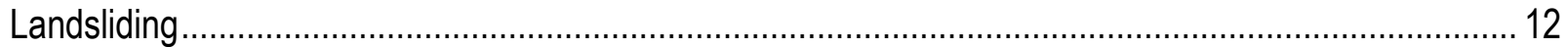

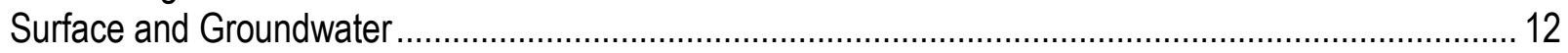

Description of Surficial Geologic Map Units, Red Rock Lakes Area, Southwest Montana......................... 13

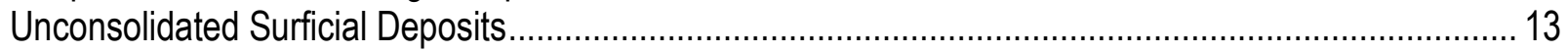

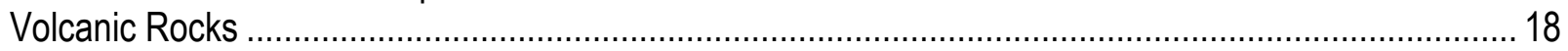

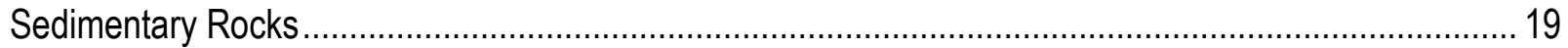

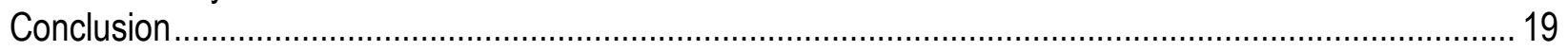

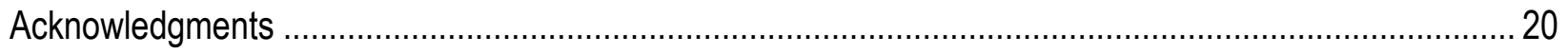

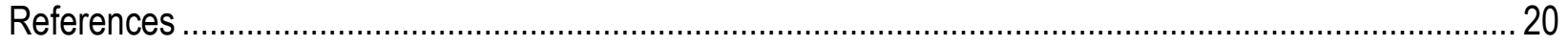




\section{Sheet}

Surficial geologic map of the Red Rock Lakes area, southwest Montana ...............................................link

\section{Figures}

1. Location of the Red Rock Lakes map area ................................................................................... 2

2. Diagrammatic cross section portraying flow of groundwater ........................................................ 10

\section{Tables}

1. Radiocarbon and calibrated ages, Red Rock Lakes area, Centennial Valley,

southwest Montana.....

2. Optically stimulated luminescence (OSL) ages of sands associated with Lake Centennial, southwest Montana.

3. Location by latitude and longitude of samples with ages shown in tables 1 and 2

\section{Conversion Factors}

Inch/Pound to SI

\begin{tabular}{|c|c|c|}
\hline Multiply & By & To obtain \\
\hline \multicolumn{3}{|c|}{ Length } \\
\hline inch (in.) & 2.54 & centimeter $(\mathrm{cm})$ \\
\hline inch (in.) & 25.4 & millimeter (mm) \\
\hline foot (ft) & 0.3048 & meter $(\mathrm{m})$ \\
\hline mile (mi) & 1.609 & kilometer $(\mathrm{km})$ \\
\hline
\end{tabular}

\section{Divisions of Quaternary and Neogene time used in this report}

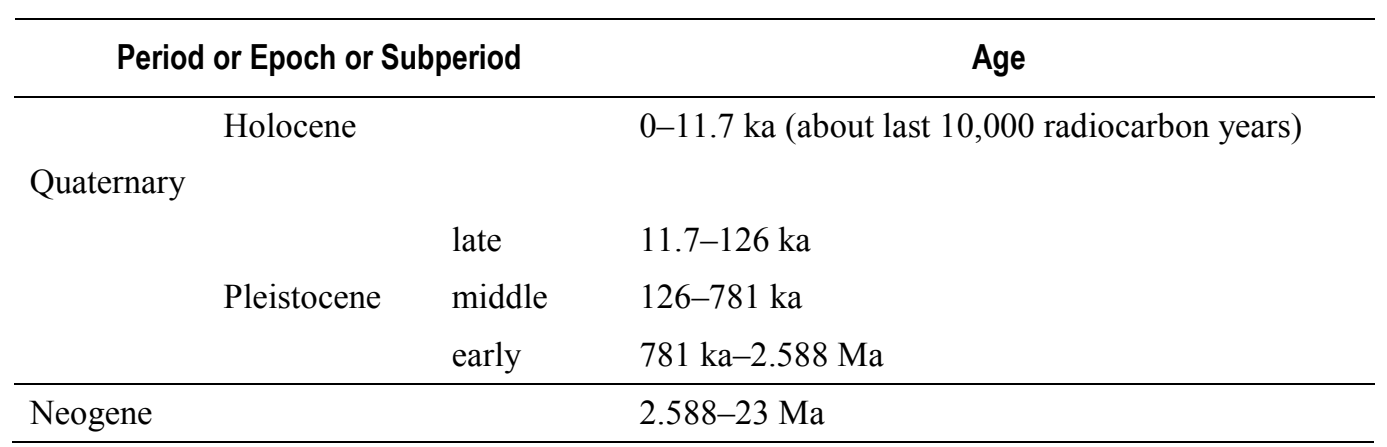

Ages of time boundaries are those of the U.S. Geological Survey Geologic Names Committee (2010). Ages are expressed in ka for kilo-annum (thousand years) and Ma for mega-annum (million years). 


\title{
Surficial Geologic Map of the Red Rock Lakes Area, Southwest Montana
}

\author{
By Kenneth L. Pierce, Tara L. Chesley-Preston, and Richard L. Sojda
}

\section{Abstract}

The Centennial Valley and Centennial Range continue to be formed by ongoing displacement on the Centennial fault. The dominant fault movement is downward, creating space in the valley for lakes and the deposition of sediment. The Centennial Valley originally drained to the northeast through a canyon now represented by a chain of lakes starting with Elk Lake. Subsequently, large landslides blocked and dammed the drainage, which created Lake Centennial, in the Centennial Valley. Sediments deposited in this late Pleistocene lake underlie much of the valley floor and rest on permeable sand and gravel deposited when the valley drained to the northeast. Cold Pleistocene climates enhanced colluvial supply of gravelly sediment to mountain streams and high peak flows carried gravelly sediment into the valley. There, the lower gradient of the streams resulted in deposition of alluvial fans peripheral to Lake Centennial as the lake lowered through time to the level of the two present lakes. Pleistocene glaciers formed in the high Centennial Range, built glacial moraines, and also supplied glacial outwash to the alluvial fans. Winds from the west and south blew sand to the northeast side of the valley building up high dunes.

The central part of the map area is flat, sloping to the west by only 0.6 meters in 13 kilometers ( 2 feet in 8 miles) to form a watery lowland. This lowland contains Upper and Lower Red Rock Lakes, many ponds, and peat lands inside the "water plane," above which are somewhat steeper slopes. The permeable sands and gravels beneath Lake Centennial sediments provide a path for groundwater recharged from the adjacent uplands. This groundwater leaks upward through Lake Centennial sediments and sustains wetland vegetation into late summer. Upper and Lower Red Rock Lakes are formed by alluvial-fan dams. Alluvial fans converge from both the south and the north to form outlet thresholds that dam the two shallow lakes upstream. The surficial geology aids in understanding how the landscapes in and around the Red Rock Lakes Wildlife Refuge were formed and how they transmit water.

This report uses metric units except for altitudes that are also given in feet because contours on the base map are in feet and the reader would have to convert from metric units to feet to understand the map relationships.

\section{Surficial Geologic History of the Red Rock Lakes Area}

The Red Rock Lakes map area covers the eastern part of the Centennial Valley located in southwestern Montana (fig. 1) and centers on the Red Rock Lakes National Wildlife Refuge. This refuge has served as a key recovery site for trumpeter swans since 1935 (U.S. Fish and Wildlife Service, 2014). The area is known for cold, snowy winters and extensive wetlands. The 
area is drained by the Red Rock River and is downstream from the uppermost headwaters of the Missouri River system. A lake once occupied the area, Lake Centennial, which was created by landslide-damming of a northern paleo-canyon of the Red Rock River (fig. 1). This late Pleistocene lake was not a typical glacial or pluvial lake, although it has been so described (Witkind, 1976; Mannick, 1980; Witkind and Prostka, 1980; Sonderegger and others, 1982b). The Centennial Mountains flank the map area to the south. Beyond the mountains lies the Eastern Snake River Plain, which is also the track of the Yellowstone hotspot (fig. 1). The hotspot track becomes younger to the northeast and is associated with late Cenozoic volcanism, faulting, and uplift that have greatly affected the geology and landscapes of the map area (Pierce and Morgan, 1992). Knowledge of the complex geologic history of this area is important to understanding the wetlands and other landscapes of the area.

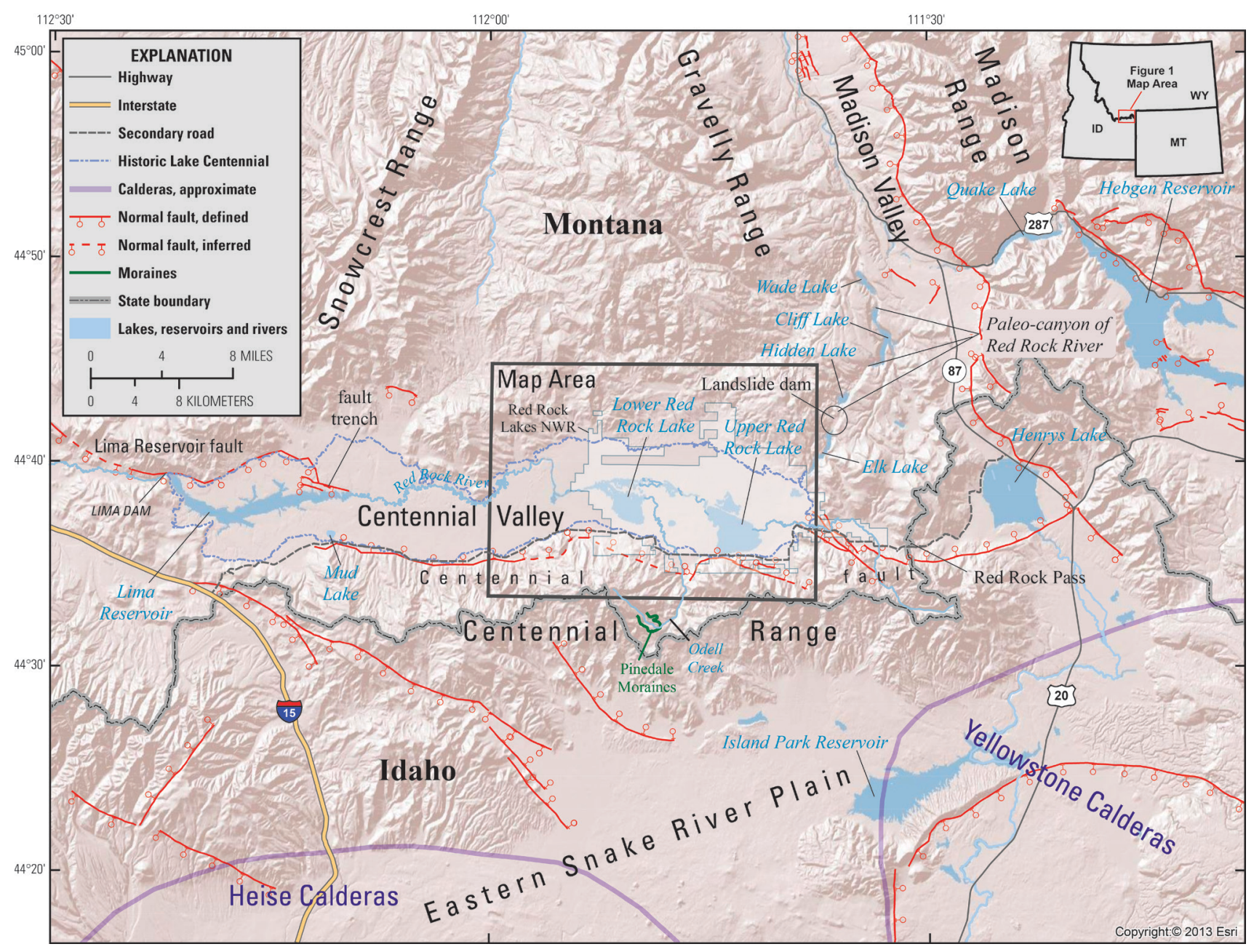

Figure 1. Location of the Red Rock Lakes map area. Note the string of lakes (Elk, Hidden, Cliff, and Wade Lakes) define a paleo-canyon of the Red Rock River northward into the Madison Valley. The eastern Snake River Plain is also the track of the Yellowstone hotspot, which is associated with late Cenozoic volcanism, faulting, and uplift (Pierce and Morgan, 1992). The two youngest caldera groupings along the hotspot track are calderas of the Heise volcanic field (6.6-4.45 Ma; Morgan and Mclntosh, 2005) and calderas of the Yellowstone volcanic field (2.05-0.64 Ma; Christiansen, 2001). Quaternary faults are shown in red and faults other than Centennial fault and the Lima Reservoir fault are from U.S. Geological Survey and Montana Bureau of Mines and Geology (2006). The Centennial 
fault extends, with right-stepping en echelon faults, from east of Henrys Lake (Myers and Hamilton, 1964; Morgan and others, 2008) through Red Rock Pass (Witkind, 1975) to the bold front of the Centennial Range east of Odell Creek. Westward from Odell Creek, the fault is poorly expressed for 15 $\mathrm{km}$ and then becomes well defined for $18 \mathrm{~km}$ to Mud Lake (Witkind, 1975; Petrik, 2008). At Mud Lake, fault offset switches to the north side of the valley as the Lima Reservoir fault (Myers and Hamilton, 1964; Bartholomew and others, 2002). This fault continues west to beneath the Lima Dam (Anastasio and others, 2010).

\section{Tectonic Setting and Active Faulting}

The Centennial Mountains and Valley are an active basin-and-range structure formed by the Centennial normal fault as a result of north-south extension. The valley continues to be created by down-faulting along the Centennial normal fault and the half graben nature of the structure results in southward tilting of the valley. Topographic surveys across the Lost River fault before and after the 1983 Borah Peak, Idaho, earthquake find that about 85 percent of the vertical fault offset is downward movement of the basin block and only about 15 percent is a result of upward movement of the mountain block (Stein and Barrientos, 1985). The map area is in the middle part of Centennial fault (fig. 1), which extends from Henrys Lake to Mud Lake (Witkind, 1975, 1976; Witkind and Prostka, 1980; Petrik, 2008).

In the map area east of Odell Creek, the Centennial Mountains consist mainly of resistant Paleozoic limestones. Along this section of the range, surface offset on the Centennial fault is clearly observed to form scarps and locally offsets Pinedale moraines about 10 meters (m). Near the base of the cliff-like range front, gently sloping Pinedale moraines intersect the fault scarpthe resulting $40^{\circ}$ or steeper slopes create very difficult footing. However, Witkind $(1975,1976)$ did not recognize what this study clearly identifies to be the main fault scarp; Witkind mapped only a minor fault scarp in the fan gravels (Qpfg) $700 \mathrm{~m}$ north of the main post-glacial fault scarp herein mapped. Right lateral offset was observed along two subsidiary fault scarps north of the main fault. The two subsidiary faults are shown on the map sheet, 1.7 and 1.8 kilometers $(\mathrm{km})$ north-northeast of Taylor Mountain where the crest of a lateral moraine is offset in a right lateral direction by 4.2 and $5.1 \mathrm{~m}$ respectively.

Throughout nearly all the map area west of Odell Creek, fault scarps were recognized in only two places even though the Centennial Mountains are as high here as east of Odell Creek. It is likely that Quaternary faulting continues through this area, but is here obscured by landsliding and mountain-scale gravitational spreading of the range in the incompetent mudstones of the Upper Cretaceous Frontier Formation. West of the map area, along the Centennial Mountains (fig. 1), fault scarps offset latest Pleistocene fan gravels about $10 \mathrm{~m}$ (Witkind, 1975; Petrik, 2008).

Dip projections of the Quaternary and Neogene tuffs (QNt) from the north side of the Centennial Valley to the south side of the Centennial Mountains indicate offset on the Centennial fault of about 1,800 m (Mannick, 1980; Morgan and others, 2008). Offset of 1,800 m of these 2.05-4.45 Ma tuffs yields a slip rate between 0.4 and 0.9 millimeters per year $(\mathrm{mm} / \mathrm{yr})$. Displacement of Pinedale moraines and fan gravels by roughly $10 \mathrm{~m}$ over the last 14,000 years (age of deglaciation) yields a slip rate of about $0.7 \mathrm{~mm} / \mathrm{yr}$, which is intermediate between the estimates of the long-term rates.

On the valley floor, north of the Centennial fault, a minor fault offsets shorelines at the edge of the "water plane" (green line on map sheet) $6 \mathrm{~km}$ north of Lakeview and extends $1.5 \mathrm{~km}$ to the northwest. Traversing southeast along this alignment, a possible fault may be responsible for the northwest strike of the straight north shore of Upper Red Rock Lake. Between these 
aligned features, Sonderegger and others (1982b, p. 19) noted a series of thermal anomalies (warm zones).

The term "fan form" is used for an alluvial fan that may be buried by lake sediments but still retains the conical form. On the Odell Creek alluvial fan-form, the following northwest trending minor faults were observed: (1) $2.7 \mathrm{~km}$ north-northeast of Lakeview, a fault scarp is noted in lidar data (Rebecca Levine, Univ. of New Mexico, written commun., 2012), and (2) 4.5 $\mathrm{km}$ northeast of Lakeview, a step-up to the northeast occurs in the opposite direction of the fan slope. In the western part of the map area, the lowland area with the label "subsided area" is lower in elevation than the lake floor of Lake Centennial and is as low or lower than the presentday Red Rock River - tectonic subsidence seems to be the only explanation for this low area at and below the base level of the river.

\section{Present-Day Lakes and Lake Centennial}

\section{Present-day Lakes and Wetlands}

Upper and Lower Red Rock Lakes are shallow lakes less than $2 \mathrm{~m}$ deep. The term "fan form" is used here to denote conical landscape units whose main shape (shown on the map by dashed dark blue arrows) was built by alluvial fan deposition, in large part prior to the deposition of Lake Centennial sediments. The threshold of the two lakes is formed by the convergence of alluvial fan-forms to make a low dam or "fan dam." The fan forms of Tepee and Odell Creeks converge from the north to south and form a threshold for Upper Red Rock Lake, and the fan forms of Metzel and Curry-Matsingale-Collins Creeks converge to make a threshold for Lower Red Rock Lake. Both lakes are located just upstream of these north-south convergences formed by large alluvial fan-forms. The modern lakes occur upstream from these "fan dams" of the Centennial Valley floor, and these constrictions act as a low threshold, or "fan dams" for the outlets of the present lakes.

The central part of the map area is a flat valley floor containing Upper and Lower Red Rock Lakes and extensive peaty marshes (Qhpc) with many small ponds, all enclosed by what is termed here as the "water plane." The "water plane" encloses a nearly horizontal wetted area that slopes west at $0.6 \mathrm{~m}$ over $12 \mathrm{~km}$ ( 2 feet in 8 miles) as measured by the altitudes of the Upper and Lower Lakes (2,015 and 2,014 m; 6,610 and 6,608 ft, respectively). This low, poorly drained area is a relic of the central part of the poorly drained Pleistocene Lake Centennial.

\section{Lake Centennial}

Lake Centennial covered a large part of the map area during the late Pleistocene (Qpl and Qpla; Witkind, 1976; Witkind and Prostka, 1980; Sonderegger and others, 1982a, 1982b; O'Neill and Christiansen, 2004; Mumma and others, 2012). A delta (Qhd) on the north side of Red Rock Creek enclosed by the 6,680-foot contour indicates the highest, well-expressed level of Lake Centennial about $20 \mathrm{~m}$ above the two modern, shallow lakes. An origin of Lake Centennial by sudden damming is inferred from an exposure (04P37, table 1) along the Red Rock River $3.5 \mathrm{~km}$ upstream from Upper Red Rock Lake. This exposure shows rhythmically bedded, deep-water lake sediments abruptly overlying alluvial gravels where no soil developed. Additionally, cores and auger holes in the map area also reveal five or more meters of lake sediments abruptly overlying either gravel or coarse sand, both inferred to be of alluvial origin. This abrupt change also supports a quick transition from a subaerial to a lake environment. One 
example is the core taken from Lower Red Rock Lake where lake sediments abruptly overlie coarse alluvial sand (Mumma and others, 2012).

The Red Rock River once flowed northeast into the Madison Valley through a paleocanyon (fig. 1) that is now highlighted by a string of steep-walled lakes beginning with Elk Lake at the south and including Hidden, Cliff, and Wade Lakes (Mansfield, 1911; Myers and Hamilton, 1964, fig. 49; Mannick, 1980; Sonderegger and others, 1982b). An extensive landslide (Sonderegger and others, 1982a) just northeast of Elk Lake blocked this northeast drainage and was responsible for damming of the Red Rock River to form Lake Centennial. Landslides presumably occurred during the late Pleistocene when climates were cooler and allowed for greater effective moisture to facilitate mass movement. Pre-Lake Centennial drainage to the northeast seems reasonable given the following altitudes. The bottom of Elk Lake (fig. 1) has an altitude of 2,013 m (6,605 ft; Lund, 1974), which combined with an estimated sediment fill of 10 $\mathrm{m}$ yields a paleo-canyon floor altitude of less than $2,004 \mathrm{~m}$, an altitude more than $11 \mathrm{~m}$ lower than Upper Red Rock Lake.

Upon damming of the drainage, Lake Centennial developed and subsequently filled high enough to release water across the paleo-divide at the western end of the Centennial Valley, which is the present location of the Lima Dam, $40 \mathrm{~km}$ west of Lower Red Rock Lake (fig. 1). The Lima dam site exposes a previous fill of alluvial fan and other sediment that projects to a water level above the dam height. Projections of the surface of the now eroded alluvial fans above the Lima Dam yield a threshold level of 0 to $20 \mathrm{~m}$ above the highest level of eastern Lake Centennial of 2,036 $\mathrm{m}(6,680 \mathrm{ft})$. The very low carbonate content of the lower $3 \mathrm{~m}$ clayey sediment in the core from Lake Centennial (location 06P49, table 3; Mumma and others, 2012) suggests the lake was not a closed basin and thus was draining. The hanging wall of the Quaternary Lima Reservoir fault is beneath the Lima Dam. The last offset on the Lima Reservoir fault is estimated to have occurred $\sim 13 \mathrm{ka}$ by Anastasio and others (2010). Three faulting events are estimated to have occurred in the last 20,000 years by Bartholomew and others (2002). During the existence of Lake Centennial, down-faulting of the Lima Reservoir fault would have lowered the outlet threshold and provided a reasonable mechanism for at least some of the decrease in water level of Lake Centennial.

Lake Centennial was dammed sometime between 30,000 and 20,000 years ago. The older age is based on ages from a core from the southern part of Lower Red Rock Lake. At that location, the lowest Lake Centennial sediments have a projected age of $\sim 28,800$ cal yr B.P. based on organic sediment 18 centimeters $(\mathrm{cm})$ above the base of the lake sediments that have a mean calibrated age of $\sim 28,135$ cal yr B.P. (table 1, location 06P49, $964 \mathrm{~cm}$, sample altitude $\sim 2,005 \mathrm{~m}$ $(6,577 \mathrm{ft})$; Mumma and others, 2012). An age of about 20,000 years derived from a very small sample of organic sediment, with a median calibrated age of 19,783 cal yr B.P., located $16 \mathrm{~cm}$ above the base of Lake Centennial clayey silts that rest on alluvial gravel [(table 1, location

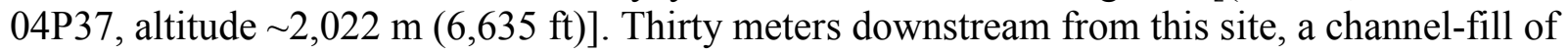
yellow sand that apparently cut into the lower part of lake sediments yielded an optically stimulated luminescence (OSL) age of $16.8 \pm 0.76 \mathrm{ka}$ (table 2, 07P49); this supports a lake margin near an altitude of $\sim 2,023 \mathrm{~m}(\sim 6,636 \mathrm{ft})$ at this time. 
Table 1. Radiocarbon and calibrated ages, Red Rock Lakes area, Centennial Valley, southwest Montana1

[cm, centimeters; mg, milligram; ft, feet; $\sim$, approximately; cal yr BP, calibrated years before present]

\begin{tabular}{|c|c|c|c|c|c|c|c|c|}
\hline $\begin{array}{l}\text { Sample field ID } \\
\text { and depth }(\mathrm{cm})\end{array}$ & WW Lab \# & Material dated & ${ }^{14} \mathrm{C}$ age & \pm & Delta ${ }^{13} \mathrm{C}$ & $\begin{array}{l}\text { Median Calib } \\
\text { age (cal yr BP) }\end{array}$ & $\begin{array}{l}\text { 2-sigma range } \\
\text { (cal yr BP) }\end{array}$ & Remarks \\
\hline \multicolumn{9}{|c|}{ 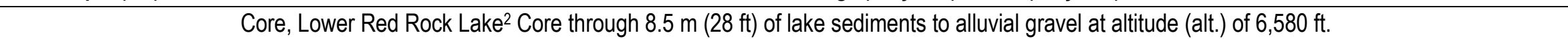 } \\
\hline 06P49, 191-192 & 6741 & Wood & 3,055 & 30 & -25 & 3,264 & $3,170-3,359$ & \multirow{5}{*}{$\begin{array}{l}\text { Core in southern part of Lower Red Rock } \\
\text { Lake also contained Mazama and Glacier } \\
\text { Peak ashes (Mumma and others, 2012). } \\
\text { Cored } 8.5 \text { m of lake sediments overlying } \\
\text { alluvial sand. }\end{array}$} \\
\hline 06P49, 470-472 & 6157 & Organic material & 10,570 & 25 & -10.25 & 12,549 & $12,426-12,625$ & \\
\hline 06Р49, 687-690 & 6158 & Plant material & 13,795 & 45 & -14.32 & 16,433 & $16,079-16,814$ & \\
\hline 06P49, 735-739 & 6172 & Organic sediment & 15,125 & 45 & -25.06 & 18,559 & $18,133-18,708$ & \\
\hline 06P49, 964 & 6173 & Organic sediment & 23,280 & 90 & -26.91 & 28,135 & $27,812-28,490$ & \\
\hline \multicolumn{9}{|c|}{ Base of well-bedded Lake Centennial sediments on alluvial gravel } \\
\hline 04P37, 500 & 5487 & Organic sediment & 16,660 & 120 & -25 & 19,783 & $19,512-20,053$ & $\begin{array}{l}\text { Base of lake sediments overlying gravel is } \\
\text { at } 6,635 \mathrm{ft} \text { altitude. Sample very small } \\
(0.08 \mathrm{mg}) \text {. }\end{array}$ \\
\hline \multicolumn{9}{|c|}{ Samples indicating lake levels near or below present } \\
\hline 03P20, 68-69 & 4745 & Peat & 735 & 30 & NA & 692 & $657-726$ & \multirow{2}{*}{$\begin{array}{l}\text { West shore, Lower RR Lake. Buried A } \\
\text { soil horizon at altitude } \sim 6,606 \mathrm{ft}\end{array}$} \\
\hline $03 \mathrm{P} 20,75-77$ & 4746 & Humic A-horizon & 12,210 & 40 & NA & 14,069 & $13,952-14,186$ & \\
\hline $05 \mathrm{P} 37,85$ & 5510 & Peat & 2,165 & 35 & NA & 2184 & $2,057-2,311$ & \multirow{3}{*}{$\begin{array}{l}\text { Core, SE shore Upper RR Lake. Present } \\
\text { altitude of dated shallow lake samples } \\
\text { now at @6,608,6,600 and 6,596 ft }\end{array}$} \\
\hline 05P37, 346-349 & 5511 & Peaty & 11,560 & 35 & NA & 13,389 & $13,287-13,491$ & \\
\hline $05 \mathrm{P} 37,455$ & 5512 & Plant filaments & 12,675 & 52 & NA & 15,019 & $14,620-15,429$ & \\
\hline $05 \mathrm{P} 132,310-314$ & 5488 & Plant fragments & 10,220 & 25 & NA & 11,942 & $11,749-12,134$ & NW of airstrip, sample from shallow lake \\
\hline \multicolumn{9}{|c|}{ Lake sediments? (silt, sand and clay) on gravel at $4.7 \mathrm{~m}$ Top of auger hole @ 6,660 ft } \\
\hline 03P14, 301 & 4750 & Organic sediment & 12,260 & 35 & NA & 14,118 & $13,933-14,534$ & $\begin{array}{l}\text { SW of Lower RR Lake. Sample alt. } \\
\sim 6,650 \mathrm{ft}\end{array}$ \\
\hline \multicolumn{9}{|c|}{ Holocene alluvium and peat accumulation } \\
\hline 05P104, 140 & 5514 & Charcoal & 3,685 & 35 & NA & 4,027 & $3,909-4,145$ & $\begin{array}{l}\text { Beneath } 140 \mathrm{~cm} \text { of overbank clayey silt } \\
\text { with weak soil along Odell Creek }\end{array}$ \\
\hline $03 \mathrm{P} 23,56-58$ & 4744 & Peat & 320 & 40 & NA & 389 & $301-483$ & $\begin{array}{l}\text { Small valley SE of Lower RR lake began } \\
\text { accumulating peat at this time }\end{array}$ \\
\hline \multicolumn{9}{|c|}{ Buried humic A-horizons in dune sand } \\
\hline 05P123, 35 & 5515 & Humic soil & 255 & 35 & NA & 300 & $(-4)-435$ & Buried A soil horizon \\
\hline 05P123, 95-100 & 5516 & A-horizon charcoal & 510 & 35 & NA & $\sim 531$ & $502-627$ & Buried A soil horizon \\
\hline
\end{tabular}

${ }_{1}^{1}$ All dates calibrated with Calib online calibration program (M. Stuiver, P.J. Reimer, and R. Reimer; http://intcal.qub.ac.uk/calib/).

${ }^{2}$ Depth is below coring platform, which is $141 \mathrm{~cm}$ above lake bottom. 
Table 2. Optically stimulated luminescence (OSL) ages of sands associated with Lake Centennial, southwest Montana.

[\%, percent; ppm, parts per million; K, potassium; U, uranium; Th, thorium; Gy, Gray or absorbed radiation energy per unit mass; ka, thousands of years; yrs, years; NaI, sodium iodide; Ge, germanium]

\begin{tabular}{|c|c|c|c|c|c|c|c|c|c|}
\hline $\begin{array}{c}\text { Sample } \\
\text { information }\end{array}$ & $\begin{array}{l}\% \text { Water } \\
\text { content }^{\mathrm{a}}\end{array}$ & $\mathrm{K}(\%)^{\mathrm{b}}$ & $\mathrm{U}(\mathrm{ppm})^{\mathrm{b}}$ & Th $(p p m)^{b}$ & $\begin{array}{c}\text { Cosmic dose } \\
\text { additions (Gy/ka) }\end{array}$ & $\begin{array}{c}\text { Total Dose } \\
\text { Rate (Gy/ka) }\end{array}$ & $\begin{array}{l}\text { Equivalent } \\
\text { Dose (Gy) }\end{array}$ & $\mathrm{n}^{\mathrm{d}}$ & $\begin{array}{l}\text { Age } \\
(k a)^{\mathrm{e}}\end{array}$ \\
\hline $12 \mathrm{P} 15$ & $4(28)$ & $1.01 \pm 0.03$ & $1.63 \pm 0.04$ & $5.15 \pm 0.23$ & $0.13 \pm 0.01$ & $1.78 \pm 0.06$ & $37.4 \pm 2.37$ & $28(30)$ & $20.8 \pm 1.53$ \\
\hline \multicolumn{10}{|c|}{ Planar bedded fine beach sand [altitude (alt.) 6,610-6,615 feet (ft)] exposed along Red Rock River 500 meters (m) downstream of Brundage Bridge } \\
\hline $12 \mathrm{P} 17$ & $16(43)$ & $2.03 \pm 0.06$ & $2.65 \pm 0.09$ & $9.45 \pm 0.38$ & $0.26 \pm 0.02$ & $3.22 \pm 0.11$ & $53.4 \pm 1.91$ & $34(40)$ & $16.6 \pm 0.82$ \\
\hline \multicolumn{10}{|c|}{ Pebbly alluvial sand (alt. 6,624 ft) above lake sediments exposed along Odell Creek $200 \mathrm{~m}$ downstream from airstrip bridge } \\
\hline 07P49 & $17(22)$ & $2.25 \pm 0.10$ & $2.52 \pm 0.12$ & $10.5 \pm 0.32$ & $0.17 \pm 0.01$ & $3.23 \pm 0.07$ & $54.1 \pm 2.27$ & $24(24)$ & $16.8 \pm 0.76$ \\
\hline \multicolumn{10}{|c|}{ Yellows alluvial sand and gravel lens in lowest part of lake sediments (alt. 6,636 ft) in bank of Red Rock Creek $200 \mathrm{~m}$ upstream from Elk Road bridge } \\
\hline 07P50 & $9(36)$ & $1.83 \pm 0.13$ & $2.28 \pm 0.08$ & $8.77 \pm 0.19$ & $0.25 \pm 0.02$ & $3.02 \pm 0.06$ & $16.9 \pm 1.22$ & $9(9)$ & $5.60 \pm 0.42$ \\
\hline \multicolumn{10}{|c|}{ Horizontally bedded sand (alt. $\sim 6,647 \mathrm{ft}$ ) near top of same section as 07P49 and unconformably beneath gravelly alluvium } \\
\hline $12 \mathrm{P} 43$ & $18(43)$ & $3.25 \pm 0.14$ & $3.87 \pm 0.16$ & $14.1 \pm 0.61$ & $0.28 \pm 0.02$ & $4.87 \pm 0.18$ & $28.1 \pm 1.62$ & $19(24)$ & $5.78 \pm 0.39$ \\
\hline
\end{tabular}

${ }^{a}$ Field moisture, with figures in parentheses indicating the complete sample saturation $\%$. Ages calculated using $25 \%$ of saturation values, except for $07 \mathrm{P} 49$ ( $75 \%$ saturation).

${ }^{b}$ Analyses obtained using laboratory Gamma Spectrometry (low-resolution NaI detector for the 2007 samples and high-resolution Ge detector for the 2012 samples).

${ }^{\mathrm{c}}$ Cosmic doses and attenuation with depth were calculated using the methods of Prescott and Hutton (1994). See text for details.

${ }^{\mathrm{d}}$ Number of replicated equivalent dose (De) estimates used to calculate the mean. Figures in parentheses indicate total number of measurements made including failed runs with unusable data.

${ }^{\mathrm{e}}$ Dose rate and age for fine-grained $150-125 \mu \mathrm{m}$ quartz sand. Linear + exponential fit used on age, errors to one sigma. 
Table 3. Location by latitude and longitude of samples with ages shown in tables 1 and 2.

\begin{tabular}{ccc}
\hline Sample & Latitude & Longitude \\
\hline 03P14 & 44.6135 & -111.8593 \\
$03 \mathrm{P} 20$ & 44.6379 & -111.8601 \\
$03 \mathrm{P} 23$ & 44.6124 & -111.8207 \\
$04 \mathrm{P} 37$ & 44.6174 & -111.6536 \\
$05 \mathrm{P} 104$ & 44.6104 & -111.8031 \\
$05 \mathrm{P} 123$ & 44.6990 & -111.8149 \\
$05 \mathrm{P} 132$ & 44.6292 & -111.8013 \\
$05 \mathrm{P} 37$ & 44.5981 & -111.6979 \\
$06 \mathrm{P} 49$ & 44.6226 & -111.8425 \\
$07 \mathrm{P} 45$ & 44.6528 & -111.9819 \\
$07 \mathrm{P} 49$ & 44.6174 & -111.6540 \\
$07 \mathrm{P} 50$ & 44.6174 & -111.6540 \\
12P15 & 44.6528 & -111.9819 \\
12P17 & 44.6128 & -111.8059 \\
$12 \mathrm{P} 43$ & 44.6174 & -111.6537 \\
\hline
\end{tabular}

Near the west map boundary, planar cross-bedded beach sands have an OSL age of 20.8 $\pm 1.53 \mathrm{ka}$, which is correlated to an early, low water phase of Lake Centennial at an altitude of 2,015-2,016 m (6,610-6,614 ft; table 2, locality 12P15; Shannon Mahan, U.S. Geological Survey, written commun., July 16, 2013). The beach sand is at least $2.4 \mathrm{~m}$ thick, extending to near the level of Red Rock River. This beach sand is buried by eolian sand with weak calcic soils consistent with an age no older than late Pleistocene.

In a section exposed in the bank of Odell Creek, interbedded sands and pink, silty clay that are interpreted to be a Lake Centennial delta yielded an OSL age of 16.6 $\pm 0.82 \mathrm{ka}$ (table 2, location 12P17; altitude of 2,019 m, 6,624 ft). Creek-bank exposures combined with augering indicate $3.7 \mathrm{~m}$ of well-bedded Lake Centennial sediments below the OSL sample that lies on preLake Centennial alluvial gravel and sand.

Pollen obtained from the core of Lower Red Rock Lake was analyzed to determine the climate and vegetation history (location 06P49; Mumma and others, 2012). The upper $3.7 \mathrm{~m}$ of the core that spans the interval 0 to 11,000 years ago is composed of marl, rich in organics (marl is used here for carbonate-rich mud), and probably post-dates Lake Centennial. Pollen from this interval indicates: (1) open pine-Douglas-fir-juniper forest from present to 2,400 years ago; (2) pine-Douglas-fir parkland steppe from 2,400 to 7,100 years ago; (3) Douglas-fir-pine forest steppe from 7,100 to 8,500 years ago; and (4) pine-forest steppe from 8,500 to 10,500 years ago. The 3.7 to $6.6 \mathrm{~m}$ depth spans an interval from 11,000 to 17,000 years ago and contains pollen that indicates spruce-pine-fir parkland. It has intermediate amounts of organics and carbonate that probably date from Lake Centennial. The 6.6 to $8.4 \mathrm{~m}$ depth spans an interval 17,000 to $28,000($ ?) years ago and has pollen indicating tundra vegetation. The sediment of this interval is silty clay and clayey silt, and is poor in both calcium carbonate and organic material, suggesting Lake Centennial was cold and deep at this time.

After a maximum lake height at an altitude of $\sim 2,036 \mathrm{~m}(\sim 6,680 \mathrm{ft}$, northeast shore $)$ the lake lowered, presumably by erosion of its outlet. On the north side of the Centennial Valley, shorelines are particularly apparent on aerial photographs (blue lines on map sheet). These shorelines may be ice-thrust shorelines because beach sands were not observed, and appear 
similar to modern ice-thrust ridges along the margin of Upper Red Rock Lake (see map sheet). Lowering of Lake Centennial is also evident by decreasing levels of delta fronts, most notably of Tepee Creek (north side of valley) and Red Rock Creek (near east side of map).

After progressive lowering of Lake Centennial to about the present lake levels (altitudes $\sim 2,014-2,015 \mathrm{~m} ; 6,608-6,610 \mathrm{ft}$ ), lake level history is complex during the 14 to $9 \mathrm{ka}$ interval, as dated by radiocarbon and OSL (tables 1 and 2). A complicating factor is southward tilting of the basin associated with the Centennial fault as well as the left lateral stepping of the fault in the eastern part of the map area (fig. 1). At the present altitude level of Lower Red Rock Lake along its west shore, a buried, dark A soil horizon yields an age of $\sim 14,000$ cal. yr B.P. (table 1, locality $03 \mathrm{P} 20,75-77 \mathrm{~cm}, \mathrm{WW} 4746$ ). This soil formed subaerially before the lake rose, which led to its burial by $68 \mathrm{~cm}$ of peat with a basal age of $\sim 700 \mathrm{cal}$ yr B.P. (table 1, 03P $20,68-69 \mathrm{~cm}$, W4745). Additionally, along the south shore of Lower Red Rock Lake, a calcareous soil on pebbly beach deposits $(\mathrm{Qpb})$ about $3 \mathrm{~m}$ above the present lake is consistent with lake levels being $3 \mathrm{~m}$ above present in latest Pleistocene time ( 15-12 ka).

Near the eastern map boundary, two samples just above the top of well-bedded Lake Centennial sediments yielded mid-Holocene ages and provide a minimum age for Lake Centennial at an altitude near $2,025 \mathrm{~m}(6,645 \mathrm{ft})$. A massive, very fine sandy silt $55 \mathrm{~cm}$ thick that is likely primary or recycled loess at the top of well-bedded Lake Centennial sediments has an OSL age of $5.78 \pm 0.39 \mathrm{ka}$. About $50 \mathrm{~m}$ downstream and above the well-bedded Lake Centennial sediments, planar bedded sands yielded an OSL age of $5.60 \pm 0.42 \mathrm{ka}$ (table 2, samples 12P43 and 07P50 respectively; Shannon Mahan, U.S. Geological Survey, written commun., July 16, 2013). Although these two ages suggest that Lake Centennial was near an altitude of 2,026 m $(6,646 \mathrm{ft})$ in mid Holocene time, an OSL age from the center of the map area indicates that Lake Centennial lowered to $2,019 \mathrm{~m}(6,624 \mathrm{ft})$ at $16 \mathrm{ka}$. Given these conflicting OSL ages as well as radiocarbon ages indicating that lake levels were near the present-day lakes in the latest Pleistocene (discussed below), it remains uncertain if Lake Centennial extended into the Holocene and therefore queries were placed along the Pleistocene-Holocene boundary in the Correlation of Map Units for Lake Centennial related deposits.

On the southeast shore of Upper Red Rock Lake, peaty organics with calibrated radiocarbon ages of $\sim 2 \mathrm{ka}$ and $\sim 13 \mathrm{ka}$ and plant fibers dating $14 \mathrm{ka}(05 \mathrm{P} 37,68-69,346-349,455$ $\mathrm{cm}$; table 1) indicate a shallow lake during these times. Down-faulting of the Centennial Valley along the Centennial fault may explain the submergence of peat and fibrous vegetation to well below the present level of the modern lakes. The Centennial fault has about $10 \mathrm{~m}$ of vertical stratigraphic offset in post-glacial time ( $\sim 14-12 \mathrm{ka})$. Such faulting tilts the basin into the fault and deepens the basin towards the fault. The outflow location of Red Rock River downstream from Lower Red Rock Lake is less affected by this tilting because the river is farther away from the fault than the southern parts of both lakes. Thus the typical half-graben tilting towards the Centennial fault would result in several meters of submergence of the southern parts of the lakes after the latest Pleistocene.

Radiocarbon dating of the lake history may be complicated by two sources of error. First, aquatic vegetation growing entirely underwater can incorporate bicarbonate dissolved from old limestone. Based on the ash-controlled age-depth plot for the Lower Red Rock Lake core (06P49), the magnitude of the error for submergent aquatic plant material could be $\sim 1,700$ years too old (sample 06P49, 470-472 cm; Mumma and others, 2012, fig. 2). Second, coal pebbles have been observed in deposits along Odell Creek derived from the Cretaceous sedimentary rocks of the Centennial Mountains west of Odell Creek. Thus, finely powdered coal may be present in Lower Red Rock Lake deposits and result in radiocarbon ages too old for dark "organic sediment" (table 1). Although numerical dating of Lake Centennial remains poorly 
resolved, this study concludes that the lake existed broadly between about 22,000 and 12,000 years ago.

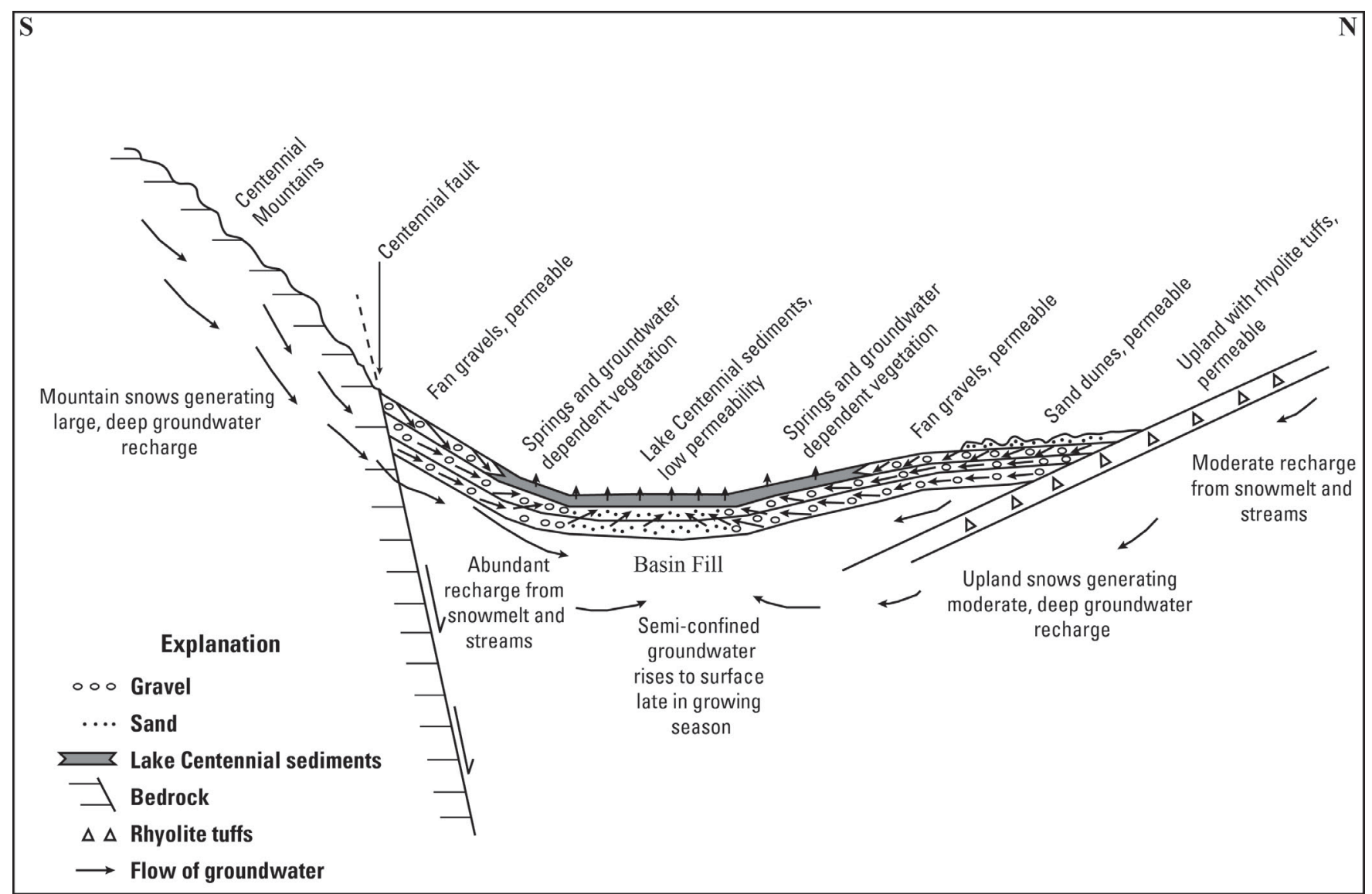

Figure 2. Diagrammatic cross section portraying flow of groundwater. Low permeability Lake Centennial sediments floor the central part of the valley and confine the groundwater in more permeable sands and gravels beneath them (see text). This semi-confined groundwater percolates upward and thus helps sustain the wetlands late in the growing season.

\section{Surficial Deposits in Western Centennial Valley}

Deposits that are correlative with Lake Centennial deposits described here are considered to be present in the western Centennial Valley (fig. 1; Myers and Hamilton, 1964; Hill and others, 2005; Anastasio and others, 2010). Along the hanging wall of the trench across the Lima Reservoir fault scarp (see fig. 1), Bartholomew and others (2002) interpreted the upper $4 \mathrm{~m}$ of fine-grained sand and silt units as loess with mostly stage II and III soil carbonate. The hanging

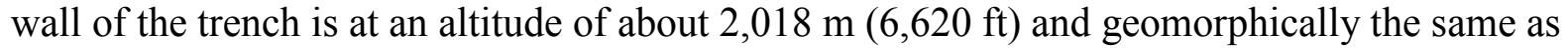
the floor of Lake Centennial elsewhere in the area. Loess thicker than half a meter is not described elsewhere on late Pleistocene deposits in the Centennial Valley (this report; Anastasio and others, 2010). We suggest that the four meters of "loess" with soil carbonate might also be interpreted as marl of lacustrine origin. 
Quaternary deposits that pre-date Lake Centennial are recognized at the Merrell vertebrate locality $0.8 \mathrm{~km}$ southeast of the Lima Dam (fig. 1). Wave-cut cliffs of the Lima Reservoir expose a rich vertebrate fauna (Hill and others, 2005). This includes a lower Stratum A of largely, poorly sorted, fine sand and sandy, silty clay of possible lake origin with ages of about $60 \mathrm{ka}$ by OSL dating and 50-45 ka by radiocarbon dating. Stratum B occurs above Stratum A and includes sediment deposited in a marsh with radiocarbon ages of $>44 \mathrm{ka}$ to $32 \mathrm{ka}$ (Hill and others, 2005).

\section{Alluvial Deposits}

Deposits of alluvial fan gravel (Qpfg) have accumulated where drainages decrease gradient and spread out from confined bedrock valleys onto the open valley floor. Transport and deposition of alluvial fan gravels were more active under Pleistocene glacial climates than under the Holocene interglacial climate (Ritter and others, 1993: Hanson and others, 2006). Compared to the present Holocene climate, the longer cold-season climate under Pleistocene conditions led to deeper accumulation of snow. Seasonal melting of these snows occurred later when solar insolation was stronger resulting in greater peak discharge (Pierce and Scott, 1982). Also, the colder Pleistocene climate enhanced colluvial movement of detritus from slopes to valley floors.

Geomorphic evidence of streams draining into Lake Centennial is recorded by subtle but steeper slopes of delta fronts (Qpd), and commonly associated alluvial fan gravels graded to these delta fronts (Qprg). These are best displayed at Red Rock, Odell, and Tepee Creeks. Such delta fronts, as well as other shoreline features, are scarce to absent on the Curry-Matsingale Creek "fan form" west of Lower Red Rock Lake.

Stream activity during Holocene time is generally restricted to present stream courses (Qal) and has built sandy deltas (Qhd) into Upper and Lower Red Rock Lakes. Along the Holocene meander belt of Odell Creek, alluvial clayey silt at a depth of $1.4 \mathrm{~m}$ has a median calibrated radiocarbon age of 4,027 years (table 1, 05P104, $140 \mathrm{~cm} ; 3,685 \pm 35 \mathrm{yr} \mathrm{BP}$ ).

\section{Glacial Deposits}

Glacial moraines of Pinedale age form bulky accumulations on the hanging wall of the Centennial fault in the southeast part of the map area (Qym). These moraines occur at the lower end of about eight very steep valleys that head in amphitheater-shaped glacial cirques on the northern front of the Centennial Range. The moraines correlate with the last glaciation, known as the Pinedale, which culminated in the northern Rocky Mountains about 18,000-15,000 years ago (Licciardi and Pierce, 2008; Thackray, 2008). These Pinedale moraines are likely piled on top of Bull Lake moraines (Qom) contributing to their bulk and large apparent volume. Glacial outwash extends northward from these moraines forming Pinedale alluvial fans (Qpfg). As diagrammed in figure 2, water from the mountain slopes infiltrates into the moraines to become groundwater flow and surface runoff, which now seldom flows across the dry outwash fans (Qpfg). The groundwater flow then reemerges as nearly continuous springs in the wetlands above the south shore of Upper Red Rock Lake.

West of Odell Creek, the terrain reaches altitudes as high as the glaciated terrain east of Odell Creek suggesting the extent of glaciation is likely to be similar, although Pinedale moraines were identified only along Collins Creek (Qym) and Odell Creek (see fig. 1). Pinedale glaciers probably also occupied valleys that head as high as Collins and Odell Creeks, but moraines are not shown on the map because they either: (1) transition to landslides farther down 
valley, or (2) are obscured by landsliding and forest cover. Possible older moraines of Bull Lake age (Qom) are mapped just east of the Odell Creek fan and along Collins Creek.

\section{Eolian Deposits}

An extensive tract of sand dunes occurs on the northern side of the Centennial Valley (Qd). The dunes stand as high as $30 \mathrm{~m}$ and form longitudinal dunes aligned southwest to northeast. This orientation appears to be the combined effect of winds from both the south and west as shown by wind rose diagrams of winds stronger than $30 \mathrm{~km}$ per hour (http://www.raws.dri.edu/cgi-bin/rawMAIN.pl? inMRED, period 1988-2010, accessed 2011). The dunes appear to be largely stable and the bulk of the sand accumulation may date from the late Pleistocene and have been deflated from the floor and beaches of Lake Centennial. Local dune areas about $10 \mathrm{~m}$ across exhibit active blowout hollows and contain rare plant species (U.S. Fish and Wildlife Service, 2009). Late Holocene eolian sand activity is indicated by dark gray, A soil horizons buried by additional eolian sand. In the northern dune area, a humic A horizon located $35 \mathrm{~cm}$ below the surface dates to about 300 years old and another A horizon located about $50 \mathrm{~cm}$ deeper dates about 500 years old (table 1, locality 05P123). A linear tract of sand dunes is also located in the west-central part of the map area in the area occupied by Lake Centennial and therefore post-dates the lake. This tract trends southwest to northeast, intersects the Red Rock River, and may act as a source of sediment building up the river level (William Locke, oral commun., 2006).

On the north side of the valley, a sheet of sand (Qsd) occurs between the highest level of Lake Centennial and dune sand $(\mathrm{Qd})$. The sand may be distributed by both wind transport to the northeast and alluvial transport to the south.

Wind-blown silt (loess) is present on alluvial (Qpfg) and lacustrine (Qpl, Qpla) deposits, but is typically only a quarter- to half-meter thick and is mixed into the underlying deposits.

\section{Landsliding}

Large landslides (QIs, Qef) are mapped on the north slope of the Centennial Range, west of Odell Creek, and are developed by incompetent mudstone and shale beds from the Cretaceous Frontier Formation. Earthflows (Qef) are mapped where lower part of landslide has lobe-like form. Landslides also are found in the northeast part of the map area and farther east, where they block an ancestral northeast drainage of the Centennial Valley that is now marked by a chain of lakes that include Elk, Hidden, and Cliff Lakes.

\section{Surface and Groundwater}

The flow of groundwater is diagrammed in figure 2. With high surface runoff during the spring snowmelt, surface water from Red Rock, Odell, Elk, Tom, and other creeks flow through the central wetland inside the "water plane" in a manner somewhat comparable to that of a freshwater lake. On a much slower time scale, water largely from snowmelt percolates down in the earth and joins the groundwater. Groundwater recharge is probably large in the high, snowy, Centennial Mountains and adjacent alluvial fans on the south side of the valley, and moderate in the lower, less snowy, upland terrains of sand dunes, alluvial fans, and rhyolite tuffs on the north side of the valley (fig. 2). Groundwater flows from the uplands towards the low, central part of the Centennial Valley. Shallow groundwater flows downslope through permeable alluvial fan gravels and then continues through fan gravels and valley-center sands that are beneath low- 
permeability Lake Centennial sediments (fig. 2). At several sites cored through Centennial Lake sediments, permeable sand and gravel were found beneath the lake sediments and groundwater commonly rose in auger holes when this aquifer was encountered.

This slow-moving groundwater dissolves soluble minerals as it percolates through the ground. In places where groundwater is at or near the surface in this semiarid landscape, evaporation and evapotranspiration concentrates the dissolved material from this groundwater. Springs and green vegetation, particularly in mid-summer, indicate where the groundwater table approaches the surface; these areas are commonly located between the upper limit of Lake Centennial sediments and the "water plane." Evaporation of groundwater is indicated by the saline-alkaline soils mapped by Nielson and Farnsworth (1965) on low beach ridges and adjacent swales that are commonly just above the "water plane" in most places except south and east of Upper Red Rock Lake.

Late in the growing season, surface water runoff diminishes significantly throughout the wetland area inside the "water plane" and groundwater works its way up through the Lake Centennial sediments and provides moisture needed for plant life. Beneath ponds and lakes in the central wetland, driving open tubes down into the upper part of the lake sediments and measurement of groundwater head commonly show upward gradients later in the growing season but locally may show downward gradients early in the growing season (Greenwood and others, 2011). Head pressures appear to be dynamic both seasonally and annually.

\section{Description of Surficial Geologic Map Units, Red Rock Lakes Area,}

\section{Southwest Montana}

\section{Unconsolidated Surficial Deposits}

Qal Alluvium (Holocene and late? Pleistocene) - Poorly consolidated alluvium of sand, gravel, and silt adjacent to and near the level of modern streams. Upper part of unit commonly fine grained (clay, silt, and sand), and rich in organic material. Lower part of the unit contains sand and gravel and may include late Pleistocene deposits, particularly at depth. Locally more than $3 \mathrm{~m}$ thick along Odell Creek, charcoal at 1.4 $\mathrm{m}$ below floodplain surface has an age of about 4,000 years (table 1, 05P104, 140 cm, WW 5514). Generally no thicker than a few meters

Qhd Delta deposits (Holocene) - Tan sand to silt, moderately well sorted. Deltas deposited by Odell Creek and Red Rock Creek and extend into present Upper and Lower Red Rock Lakes. Odell Creek delta has "bird foot" form. Probably a few meters thick

Qhss Silty shoreline complex (Holocene) - Silty shorelines along north shore of Upper Red Rock Lake. Built by the lake at present level with crests no more than a half meter above Upper Red Rock Lake. Complex consists of about five linear shorelines that trend southeast-northwest and were built successively to the southwest. The southern face of the shorelines is commonly water saturated and can act like a "quick-silt" if walked on. Shorelines of muddy silt were probably created by the wind driving lake ice and shallow-lake sediments northeastward into the shore and are formed by a similar process to peaty thrust ridges shown on the south and southwest shore of Upper Red Rock Lake. The linear trend of the shorelines over several kilometers 
may have been controlled by offset along a postulated WNW-trending fault at the northern margin of the shoreline complex. Thickness probably a few meters

Qsd Alluvial and eolian sand undivided (Holocene and late Pleistocene) - Tan sand, mostly fine and medium grained, with a well-drained soil. Forms gently sloping sand sheet that contrasts with higher local relief of nearby sand dunes. Mapped east of Teepee Creek where deposit has an overall gentle south slope as well as low slopes parallel to local drainages from the northeast. Mapped west of Teepee Creek between dune sands and lake sediments at and above upper level of the late Pleistocene lake (altitude $\sim 6,670$ feet). Unit may be a combination of sandy alluvium washed south from dune and eolian sand deflated from Pleistocene lake sediments

Qd Dune sand (Holocene and late Pleistocene) - Tan, fine to medium grained, well-sorted sand, with a well-drained soil. Sand grains rounded and frosted. Forms linear sand dunes with northeasterly orientation that is the combined result of westerly and southerly winds, as shown by wind rose diagrams (http://www.raws.dri.edu/cgibin/rawMAIN.pl? inMRED, period 1988-2010, accessed 2011). The main dune accumulation was probably in late Pleistocene time. Local continued activity indicated by shallow buried soil horizons that at $35 \mathrm{~cm}$ deep, dates about 300 years old and at 95-100 cm deep dates about 530 years old (location 05P123; table 1). Also includes blow-outs with active, poorly vegetated sand. Thickness $1 \mathrm{~m}$ to $\sim 30 \mathrm{~m}$

Qls Landslide deposits, undifferentiated (Holocene and late Pleistocene) - Coarse rock fragments in a muddy matrix. Irregular surface topography with undrained or poorly drained depressions. Landslides with less definitive topographic expression are probably more extensive than mapped in the irregular mountain slopes south of Lower Red Rock Lake. In northeast part of map area, the main landslide area was mapped by Sonderegger and others (1982a) as "Huckleberry Ridge Tuff-displaced by mass wasting" and smaller area near northern boundary as "Tertiary basaltdisplaced by mass wasting." In northeast corner of map area and farther east, landslides of Huckleberry Ridge Tuff dammed an old drainage of Red Rock River now partly occupied by Elk Lake. Irregular topography mapped near Matsingale Creek southwest of Lower Red Rock Lake mapped as “Qls?” is questioned because it may also include Pinedale glacial moraines

Qef Earthflow deposits (Holocene and late Pleistocene) — Coarse, angular rock fragments in a muddy matrix. Deposit has flow-like form with levee-like marginal ridges, lobelike form in lower part, and generally a steep front at its lower end. Irregular surfaces include undrained depressions. Probably mostly active in the late Pleistocene, but locally steep fronts near angle of repose suggest some Holocene activity. A waterwell drilled into and through the earthflow west of Lakeview encountered waterbearing gravel that is probably the same gravel mapped as "thrust gravel" (see Qtg) beyond the toe of the earthflow

Qhpc Peat of central wetland (Holocene) - Peat, dark brown, fibrous. Occurs inside "water plane" denoted by green line, where peaty soils support extensive beaked sedge (Carex utriculata) vegetation. "Water plane" is nearly a flat surface in the central part of valley that slopes very gently to the west $(0.6 \mathrm{~m}$ in $12 \mathrm{~km} ; 2$ feet in 8 miles $)$ and is wetted during much of the growing season. The peat is $0.5 \mathrm{~m}$ or more thick and locally overlies a buried humic paleosol. Two ages from the base of the peat 
located in the western part of the central lowland peat are $\sim 700$ years ago $(03 \mathrm{P} 20)$ and 2,200 years ago (05P37; table 1). Below peat of the central wetland are lake sediments, ranging from pale-tan, shelly marl, silty clay, to fine sand. Location of "water plane" is locally marked by areas of rush (Juncus balticus) that is nearly black on aerial photographs and is just above and outside the "water plane." Lack of oxidation of peat over time indicates long-term saturated conditions probably due to upward percolation of groundwater (fig. 2). Unit surrounds Upper and Lower Red Rock Lakes and many shallow ponds that are shown by blue color. May locally contain alluvial sand and silt

Qhpa Peat above water plane (Holocene) - Fibrous, dark brownish-gray peat formed mostly from sedge (Carex) and willows. Separately mapped above the "water plane" in only two areas - (1) southeast of Lower Lake, and (2) east of Upper Lake, although local peat occurs elsewhere. Peat one-half to several meters thick. Associated with emergent spring water and spongy ground on terrain that slopes gently towards the lakes

Qpfg Alluvial fan gravel (late Pleistocene) - Gravel with interbeds of silt, sand, and mud. For alluvial fans of larger drainages, gravel is subrounded. For smaller drainages gravel is subangular and platy. Upper meter is commonly mixed with loess and other fine material. Exposures deeper than a meter are very rare but at depth are probably clast supported gravels with a well-washed sand matrix as indicated by exposures into the older but similar gravel (thrust gravel, Qotg) near Lakeview. Lithology of gravel reflects the bedrock upslope. For fan gravel derived from the Centennial Range east of Odell Creek, gravel clasts mostly limestone and deposited as outwash associated with glacial moraines at foot of the range. Locally adjacent to glacial moraines, includes bouldery mounds suggestive of debris flows. For fan gravels west of Odell Creek, gravel clasts mostly basalt, rhyolite, quartzite, and sandstone. For fan gravel north of Upper and Lower Red Rock Lakes, pebble gravel is rich in rhyolite tuff. Alluvial fan gravel (Qpfg) generally has weak calcic soil horizon 50-75 cm thick and only thin $(1 \mathrm{~mm})$ carbonate coats on underside of stones. Probably overlies similar but older alluvial fan gravels deposited as the Centennial Valley aggraded during Quaternary time. Water from Centennial Range percolates through alluvial fan gravel (Qpfg) and nourishes band of darker vegetation inferred to be associated with less permeable lake sediments (Qpla; fig. 2). Although alluvium (Qal) is mapped along larger drainages where topographically inset into this map unit (Qpfg), smaller, narrow bands of Holocene alluvium are not mapped separately

Qfgu Undifferentiated fan gravel (late Pleistocene) - Small alluvial and colluvial fans of small, intermittent drainages. Mapped along range front between the larger fans and larger drainages. Sorting less than that of fans from larger drainages and may include debris flow deposits. Clasts are typically subangular. The fan surface is generally of late Pleistocene age, but probably overlies older fan gravel

Qprg Recessional alluvial fan gravel and sand (late Pleistocene) - Forms pie-shaped sectors of alluvium graded to deltaic lake-margin deposits at and below the upper level $(2,036 \mathrm{~m}, 6,680 \mathrm{ft})$ of Lake Centennial. Similar to alluvial fan gravel (Qpfg), and the unit formed as Lake Centennial receded and the larger streams (Odell, Red Rock, Tom, and Tepee Creeks) prograded to increasingly lower altitudes. Thickness 
roughly 1-2 m. Gravel and sand composition reflect the source of sediment carried by the streams, as described for Pleistocene alluvial fan gravel (Qpfg)

Qpla Lake Centennial deposits and alluvium (late Pleistocene) - Complex of fine-grained, bedded lake sediments and alluvium. Alluvium consists of gravelly sand to sandy mud and becomes thinner and finer towards the valley axis. Mapped on south side of the Centennial Valley where unit has morphology of low gradient "fans" but the surface slope of deposit is commonly much less than that of the alluvial fan gravel (Qpfg) farther upslope. Upper limit of unit inferred from dark vegetation indicates groundwater emergence thought to be associated with low permeability lacustrine sediment. The conical "fan" form of the complex is considered to be largely inherited from that of older Pleistocene alluvial fans buried by Lake Centennial sediments (Qpl). Map unit commonly capped with several decimeters of loess. Recognizable shorelines are only locally mapped on south side of the Centennial Valley in contrast to shorelines being common on north side of the valley. South and east of Upper Red Rock Lake, the upper limit of unit is quite uncertain but mapped to include wet, peaty ground. Along Odell Creek $1.5 \mathrm{~km}$ north of Lakeview, a combined bluff and auger section displays the following units: $0-30 \mathrm{~cm}$ pebbly sandy loam, (alluvial), grayish brown A and B soil horizons; $30-40 \mathrm{~cm}$ pebbly sand, white (dry) Bk horizon; 40-75 cm silt and fine sand, Bk horizon; 75-130 cm silt and very fine sand, beds 5-10 cm thick, effervesces weakly; 130-180 cm three couplets of tan sand grading upward into pink clayey silt, interpreted to be deltaic alluvial sand capped by lake sediment (middle sand has OSL age of $16.6 \pm 0.82 \mathrm{ka}$, locality 12P17, table 2); 180-270 cm bedded dark gray silt, pink clayey silt, and very fine sand, effervesces strongly (lacustrine); $270-430 \mathrm{~cm}$ well-bedded dark gray silt and pink clayey silt, varved(?), effervesces weakly; 430-450 cm sandy interval, coarse to fine sand beds; 450-520 cm well-bedded dark gray silt and pink clayey silt, effervesces weakly; 520-550 cm gravel and sand, water rises in hole (aquifer). Section contains small coal pebbles

Qpl Lake Centennial deposits (late Pleistocene)—Well-bedded sand, silt, and clay. Sandy near surface generally grading downward to silt and silty clay. Oxidizes to tan but fresh auger and core samples are greenish-gray below water table. On north side of valley, upper lake margin at $\sim 6,670-6,680 \mathrm{ft}$ altitude. Upper part of lake sediments generally effervesces strongly in hydrochloric acid whereas lower part effervesces moderately to quite weakly. On north side of Centennial Valley and in western part of map area, unit occurs adjacent to extensive sand dunes and lake sediments that may in part result from lacustrine reworking of old eolian sand that predates Lake Centennial. Surface of deposit commonly shows low horizontal shoreline ridges (shown by blue lines on map), notably apparent on aerial photographs and may be either beach deposits or ridges formed by wind-driven thrusting of lake ice into shore. Deposit mantled with $20-50 \mathrm{~cm}$ of loess. Lake sediments may be locally overlain by thin alluvium and eolian sand, and silt. Adjacent to Culver Pond dam, lacustrine deposits are $5 \mathrm{~m}$ thick that grade upward from clayey silt to silt to interbedded silt and fine sand and to fine sand. Above the lacustrine deposits is pebbly, alluvial sand in which a soil with a calcic horizon $75 \mathrm{~cm}$ thick is developed. Below the lake sediment is $>1 \mathrm{~m}$ of sandy gravel, which makes a good aquifer (fig. 2). Along Red Rock River near the west margin of the map, well-sorted beach sand with low-angle planar cross beds yielded optically stimulated luminescence (OSL) 
age of $20.8 \pm 1.53 \mathrm{ka}$ (locality $12 \mathrm{P} 15$, altitude $\sim 6,610-6,615 \mathrm{ft}$, table 2; Shannon Mahan, U.S. Geological Survey, written commun., July 16, 2013). This deposit apparently represents a low level of Lake Centennial in its early history. Along Red Rock Creek near east margin of map, the base of varved(?) Lake Centennial sediments have a median calibrated radiocarbon age of 19,783 years (locality 04P37, altitude $\sim 6,635 \mathrm{ft}$, table 1, John McGeehin, written commun., 2006) and an alluvial sand nearby in the lower part of the Lake Centennial sediment has as OSL age of $16.8 \pm 0.76 \mathrm{ka}$ (locality $07 \mathrm{P} 49$, altitude $\sim 6,636 \mathrm{ft}$, table 2 ).

Qpd Lake Centennial deltaic deposits (late Pleistocene) - Sand and gravel deposits of larger streams at and below the upper level of Lake Centennial. Generally recognized by: (1) steeper slope of inferred delta front, (2) horizontal trend of inferred shoreline at lower margin of deposit, and (3) location downslope from pie-shaped sectors of alluvial fan sediments. Along east map boundary on north side of Red Rock Creek, map unit includes delta top at 6,680 foot contour, which is the highest Lake Centennial delta mapped

Qpb Low beach and shoreline ridges (late Pleistocene?) — Sand, silt, and pebble gravel forming shoreline(s) within 3 m elevation of Upper and Lower Red Rock Lakes. Mapped only where topographically expressed. On south shore of Lower Red Rock Lake, sand and pebbly sand has an alkaline calcic soil with 50-cm-thick, light tan Bk horizon that probably indicates late Pleistocene age. On north shores of Lower and Upper Red Rock Lakes, locally forms low ridges of silt and sandy silt that may be of ice-thrust origin and younger than the Pleistocene

Qym Glacial moraines, younger (late Pleistocene, Pinedale glaciation) - Unsorted deposits of gravel, sand, silt, and clay. East of Odell Creek on north side of Centennial Range, forms bouldery morainal ridges rich in limestone and some Precambrian green schist. Moraines at the five valley mouths that were examined have steep distal slopes $\left(>25^{\circ}\right)$ and undrained depressions indicating a Pinedale rather than Bull Lake age. Moraines mostly forested with small meadows. Sharp-crested moraines are offset $\sim 10 \mathrm{~m}$ by the Centennial fault. South of the map area, Pinedale moraines occur along Odell Creek (fig. 1). West of Odell Creek, the only Pinedale moraine mapped is along the valley of Collins Creek (the drainage east of Curry Creek) where glacial deposits contain clasts of basalt, quartzite (some striated), sandstone, and rhyolite. Deposits support a mosaic of forest and meadows. Farther down Collins Creek valley, material mapped as questionable landslide (Qls?) probably includes Pinedale morainal material. Centennial Mountains west of Odell Creek are as high as the glaciated range east of Odell Creek and probably supported unmapped Pleistocene glaciers, but moraines were not observed in this rugged, forested, extensively landslid terrain

Qofg Older fan gravel (middle? Pleistocene, Bull Lake glaciation?) —Gravel, poorly sorted with boulders up to a meter across. Only deposit mapped is just south of Upper Red Rock Lake Campground. Well-developed Bk soil horizon with continuous carbonate in matrix and carbonate coats on stones 2-4 mm thick. Forms low mound with younger fan gravel inset on west and east sides. Limestone boulders on surface have 5-10 cm deep weathering pits 
Qtg Thrust gravel (middle? Pleistocene, Bull Lake glaciation?) - Coarse, rounded gravel, clast supported with a sandy matrix. Located just north of Lakeview at leading margin of large earthflow. Surface of gravel forms ridges inferred to form by imbricate thrusting of alluvial gravel driven by the weight of the earthflow upslope. Soil Bk horizon more than half a meter thick with carbonate coats $\sim 2 \mathrm{~mm}$ thick indicates a Pinedale or older age for the original gravel whereas the inferred landslide-driven thrusting occurred later; perhaps continuing into the Holocene. In well drilled for Lakeview bunkhouse, this gravel deposit overlies clayey sediment and thus the gravel may have been thrust along the top of this clayey sediment

Qom Glacial moraine, Older (middle Pleistocene, Bull Lake age?)—East of Odell Creek, mapped where Alden (1953, p. 175) distinguished an older moraine into which a valley was eroded by "an interglacial stage of stream erosion" prior to deposition of the younger (Pinedale) moraines. West of Odell Creek and down valley from Pinedale moraines of Collins Creek (the stream east of Curry Creek), mapped as "Qom?" for gentle, arcuate ridge and swale deposit studded with very large, scattered boulders. An alternate interpretation is that the deposit is an old landslide with subdued arcuate ridges that resemble end moraines

Qbd Upland bench deposits (early Pleistocene?) - Bouldery bench deposits in southwest part of map area. An 8-m-thick section exposes mostly subangular to angular basalt boulders in matrix-supported, debris-flow deposit. Rounded reworked quartzite clasts are locally common as well as some clasts of porous limestone. Although considered by Witkind and Prostka (1980) to be a pediment deposit, local thickness, boulders, and matrix-supported fabric indicate at least part of unit is a thick debris flow deposit. Carbonate coats, $0.5 \mathrm{~cm}$ thick, and deep incision indicate an age considerably older than the last glaciation (Pinedale)

\section{Volcanic Rocks}

Qba Basalt, (early Pleistocene?) —Dark gray, dense basalt with sparse olivine phenocrysts. Mapped only south of Elk Lake where it has K-Ar age of $1.95 \pm 0.35 \mathrm{Ma}$ and considered to be younger than Quaternary Huckleberry Ridge Tuff (Sonderegger and others, 1982a, 1982b)

QNt Welded tuffs (early Pleistocene and Neogene) - Siliceous rhyolite with phenocrysts of quartz and feldspar. Pinkish-gray, gray to brown welded tuff. Forms much of the terrain on north side of map area where it dips gently ( $\sim 5$ degrees) to the south as a result of tilting toward the active Centennial normal fault. Although mapped as the Huckleberry Ridge Tuff by Sonderegger and others (1982a), and O'Neill and Christiansen (2004), much of this unit probably includes older tuffs. The Kilgore Tuff $(4.45 \pm 0.05 \mathrm{Ma})$ is recognized in this area (Morgan and McIntosh, 2005, figure 2A). Robert Christiansen (2001, plate 3, and written commun., 2012) mapped only the southern part of the area between Elk Lake and Tepee Creek as Huckleberry Ridge Tuff and mapped the larger, remaining northern part of the map area as tuff that predated the Huckleberry Ridge Tuff. The 2.05 Ma Huckleberry Ridge Tuff is the first and largest major eruption from the Yellowstone volcanic field to the southeast of the map area (fig. 1) (Christiansen, 2001), whereas the older tuffs 
originated from the Heise volcanic field (4.4 to $6.6 \mathrm{Ma}$ ) to the south and southwest of the map area (fig. 1; Morgan and McIntosh, 2005)

Nba Basalt (Neogene) - Dark gray basalt. Upper part of flow is vesicular and middle part is commonly columnar jointed. Commonly contains small olivine phenocrysts. Weathers to reddish iron-oxide colors. Mapping after Sonderegger and others (1982a) where classified as "Pliocene"

\section{Sedimentary Rocks}

Ns Sedimentary rocks (Neogene) - Light gray to cream, dense limestone and light gray to off-white, fine- to medium-grained sandstone. This unit includes both Tertiary sandstone and Tertiary limestone of Sonderegger and others (1982a, their units Ts and TIs, respectively) and compiled as Sixmile Creek Formation by O'Neill and Christiansen (2004). Occurs on slopes on the north side of map where it is overlain by upper Cenozoic tuffs. Mapping after Sonderegger and others (1982a) where unit classified as lower Miocene(?)

\section{Conclusion}

Ongoing offset on the Centennial fault has created the Centennial Valley and Centennial Range. Offset is dominantly ( $\sim 85$ percent) by downward movement of the valley side of the fault. This downward movement of the Centennial Valley creates space for sediment to accumulate as sediment is carried by streams by erosion of the adjacent bedrock uplands. The valley once drained north through a paleo-canyon into the Madison Valley, and the Centennial Valley was drained by an axial stream depositing sand and gravel and flanked by gravelly alluvial fans. This canyon was then blocked by landslides to create Lake Centennial. Sediments of this late Pleistocene Lake Centennial compose the floor of the central part of the valley and are flanked on the north and south by late Pleistocene alluvial fans (Qpfg). Cold Pleistocene climates enhanced colluvial supply of gravelly sediment to mountain streams and high peak flows carried gravelly sediment into the valley where the lower gradient of the streams resulted in deposition of alluvial fans. At this time, Pleistocene glaciers built glacial moraines (Qym) and also supplied glacial outwash to the alluvial fans. As Lake Centennial lowered, presumably by erosion of its outlet near Lima Dam, lower shorelines and deltas (Qpd) formed. During and after the drainage of Lake Centennial, winds from the southwest blew sand to the northeast side of the valley creating high sand dunes $(\mathrm{Qd})$.

The central part of the map area is nearly horizontal, sloping to the west only $0.6 \mathrm{~m}$ in 13 $\mathrm{km}$ ( 2 feet in 8 miles). This forms a flat, watery, lowland that contains upper and lower lakes, many ponds, and peat lands included inside the nearly flat "water plane" that is bounded by somewhat steeper slopes. Beneath the sediments of Lake Centennial are permeable sands and gravels that host groundwater recharged by surface and subsurface flows from the adjacent mountains and uplands (fig. 2). Groundwater from these sands and gravels leaks upward to sustain local vegetation adjacent to and within the central wetland (fig. 2). Alluvial fans converge from both the south and the north to form thresholds that serve as outlets for Upper and Lower Red Rock Lakes held upstream. Understanding of this surficial geology enhances understanding of how the landscapes operate in and around the Red Rock Lakes National Wildlife Refuge. 


\section{Acknowledgments}

The radiocarbon ages were provided by Jack McGeehin of the U.S. Geological Survey (USGS). Shannon Mahan of the USGS graciously provided and discussed the OSL ages. Jim Schmidt offered expertise on interpretation of some sediment exposures. Steve Custer critiqued the section on groundwater. Stephanie Mumma and Cathy Whitlock studied the core from Lower Red Rock Lake. Bill West, Mike Parker, Jeff Warren, and Jackie Vann of the Red Rock Lakes National Wildlife Refuge provided help in many ways. Lois Walsh graciously granted access to the moraines and the Centennial fault in the eastern part of the map area. Malvina Adolph, Ashley Yearous (Jaquez), Aurelie Dufour, Matt Trebesch, R. Hayes Buxton, and Don Rosenberry helped with the field and office work. We thank Marith Reheis, Bill Locke, and Linda Pierce for very helpful reviews of this report. Christine Chan and Lisa Ramirez Rukstales edited this report and prepared the map and text for release.

\section{References}

Alden, W.C., 1953, Physiography and glacial geology of western Montana and adjacent areas: U.S. Geological Survey Professional Paper 231, 200 p., 4 plates.

Anastasio, D.J., Majerowicz, C.N., Pazzaglia, F.J, and Regalla, C.A., 2010, Late PleistoceneHolocene ruptures on the Lima Reservoir fault, SW Montana: Journal of Structural Geology, v. 32, no. 12, p. 1996-2008.

Bartholomew, M.J., Stickney, M.C., Wilde, E.M., and Dundas, R.G., 2002, Late Quaternary paleoseismites - Syndepositional features and section restoration used to indicate paleoseismicity and stress-field orientations during faulting along the main Lima Reservoir fault, southwestern Montana, in Ettensohn, F.R., Rast, Nicholas, and Brett, C.E., eds., Ancient seismites: Boulder, Colorado, Geological Society of America Special Paper 359, p. 29-47.

Christiansen, R.L., 2001, The Quaternary and Pliocene Yellowstone Plateau volcanic field of Wyoming, Idaho, and Montana: U.S. Geological Survey Professional Paper 729-G, 145 p., 3 plates.

Greenwood, M.C., Sojda, R.S., Sharp, J.L., Peck, R.G., and Rosenberry, D.O., 2011, Multi-scale clustering of functional data with application to hydraulic gradients in wetlands: Journal of Data Science, v. 9, no. 3, p. 399-426.

Hanson, P.R., Mason, J.A., and Goble, R.J., 2006, Fluvial terrace formation along Wyoming's Laramie Range as a response to increased late Pleistocene flood magnitudes: Geomorphology, v. 76, p. 12-25.

Hill, C.L., Albanese, J.P., Dundas, R.G., Davis, L.B., Batten, D.C., Herbort, D.P., Huber, J.K., Mulholland, S.C., Feathers, J.K., and Root, M.J., 2005, The Merrell Locality and Centennial Valley, Southwest Montana: Bureau of Land Management Cultural Resources Series No. 4, 2005, $166 \mathrm{p}$.

Licciardi, J.M., and Pierce, K.L., 2008, Cosmogenic exposure-age chronologies of Pinedale and Bull Lake glaciations in greater Yellowstone and the Teton Range, USA: Quaternary Science Reviews, v. 27, issues 7-8, p. 814-831, doi:10.1016/j.quascirev.2007.12.005.

Lund, J.A., 1974, The reproduction of salmonids in the inlets of Elk Lake, Montana: Bozeman, Montana State University, M.S. Thesis, 43 p.

Mannick, M.L., 1980, The geology of the northern flank of the upper Centennial Valley, Beaverhead and Madison Counties, Montana: Bozeman, Montana State University, M.S. Thesis, 86 p. 
Mansfield, G.R., 1911, The origin of Cliff Lake, Montana: Geographical Society of Philadelphia Bulletin, v. 9, no. 2, p. 10-19, 3 pls.

Morgan, L.A., and McIntosh, W.C., 2005, Timing and development of the Heise volcanic field, Snake River Plain, Idaho, western USA: Geological Society of America Bulletin, v. 117, p. 288-306.

Morgan, L.A., Pierce, K.L., and Shanks, W.C., 2008, Track of the Yellowstone hotspot-Young and ongoing geologic processes from the Snake River Plain to the Yellowstone Plateau and Tetons: Geological Society of America Field Guide 10, p. 139-173.

doi:10.1130/2008.fld010(08).

Mumma, S.A., Whitlock, Cathy, Pierce, Kenneth, 2012, A 28,000 year history of vegetation and climate from Lower Red Rock Lake, Centennial Valley, southwestern Montana, USA:

Palaeogeography, Palaeoclimatology, Palaeoecology, v. 326-328, p. 30-41.

Myers, W.B., and Hamilton, Warren, 1964, Deformation accompanying the Hebgen Lake earthquake of August 17, 1959, chap. I of The Hebgen Lake, Montana Earthquake of August 17, 1959: U.S. Geological Survey Professional Paper 435, p. 55-98.

Nielson, E.C., and Farnsworth, D.N., 1965, Soil survey handbook for Red Rock Lakes Migratory Waterfowl Refuge in survey area 061: U.S. Department of Agriculture Soil Conservation Service, Dillon Field Office.

O’Neill, J.M., and Christiansen, R.L., 2004, Geologic map of the Hebgen Lake quadrangle, Beaverhead, Madison, and Gallatin Counties, Montana, Park and Teton Counties, Wyoming, and Clark and Fremont Counties, Idaho: U.S. Geological Survey Scientific Investigations Map 2816, scale 1:100,000.

Petrik, F.E., 2008, Scarp analysis of the Centennial Normal Fault, Beaverhead County Montana and Fremont County, Idaho: Bozeman, Montana State University, M.S. Thesis, 287 p.

Pierce, K.L., and Morgan, L.A., 1992, The track of the Yellowstone hot spot: Volcanism, faulting, and uplift, in Link, P.K., Kuntz, M.A., and Platt, L.B., eds., Regional geology of eastern Idaho and western Wyoming: Geological Society of America Memoir 179, 1 color map, p. 1-53.

Pierce, K.L., and Scott, W.E., 1982, Pleistocene episodes of alluvial-gravel deposition, southeastern Idaho, in Bonnichsen, Bill, and Breckenridge, R.M., eds., Cenozoic geology of Idaho: Idaho Bureau of Mines and Geology Bulletin 26, p. 685-702.

Prescott, J.R., and Hutton, J.T., 1994, Cosmic ray contributions to dose rates for luminescence and ESR dating - Large depth and long-term variations: Radiation Measurements, v. 23, p. 497-500.

Ritter, J.B, Miller, J.R., Enzel, Y., Howes, S.D., Nadon, G., Grubb, M.D., Hoover, K.A., Olsen, T., Runeau, S.L., Sack, D., Summa, C.L., Taylor, I., Touysinhthiphonexay, K.C.N., Yodis, E.G., Schneider, N.P., Ritter, D.F., and Wells, S.G., 1993, Quaternary evolution of Cedar Creek alluvial fan, Montana: Geomorphology, v. 8, no. 4, p. 287-304.

Sonderegger, J.L., Berg, R.B., and Mannick, M.L., 1982a, Geologic map of the northern part of the Upper and Lower Red Rock Lake quadrangles, Beaverhead and Madison Counties, Montana: sheet 1, scale 1:62,500, in Sonderegger, J.L., Schofield, J.D., Berg, R.B., and Mannick, M.L., 1982, The upper Centennial Valley, Beaverhead and Madison Counties, Montana-An investigation of resources utilizing geological, geophysical, hydrochemical, and geothermal methods: Montana Bureau of Mines and Geology Memoir 50, 53 p., 3 sheets.

Sonderegger, J.L., Schofield, J.D., Berg, R.B., and Mannick, M.L., 1982b, The upper Centennial Valley, Beaverhead and Madison Counties, Montana-An investigation of resources utilizing geological, geophysical, hydrochemical, and geothermal methods: Montana Bureau of Mines and Geology Memoir 50, 53 p., 3 sheets. 
Stein, R.S., and Barrientos, S.E., 1985, Planar high-angle faulting in the Basin and Range: Geodetic analysis of the 1983 Borah Peak, Idaho, earthquake: Journal of Geophysical Research, v. 90, no. B13, p. 11,355-11,366.

Thackray, G.D., 2008, Varied climatic and topographic influences on late Pleistocene mountain glaciation in the western United States: Journal of Quaternary Science, v. 23, no. 6-7, p. 671681.

U.S. Geological Survey Geologic Names Committee, 2010, Divisions of geologic time-Major chronostratigraphic and geochronologic units: U.S. Geological Survey, Fact Sheet 2010-3059, $2 \mathrm{p}$.

U.S Fish and Wildlife Service, 2009, Comprehensive Conservation Plan, Red Rock Lakes National Wildlife Refuge, 196 p.

U.S Fish and Wildlife Service, 2014, Red Rock Lakes National Wildlife Refuge, Montana: accessed June 2014, at http://www.fws.gov/nwrs/threecolumn.aspx?id=2147522787.

U.S. Geological Survey and Montana Bureau of Mines and Geology, 2006, Quaternary fault and fold database for the United States, accessed Jan. 30, 2013, from USGS web site: http://earthquake.usgs.gov/hazards/qfaults/.

Witkind, I.J., 1975, Geology of a strip along the Centennial fault, southwestern Montana and adjacent Idaho: U.S. Geological Survey Miscellaneous Investigations Series Map I-890, scale $1: 62,500$.

Witkind, I.J., 1976, Geologic map of the southern part of the Upper Red Rock Lake quadrangle, southwestern Montana and adjacent Idaho: U.S. Geological Survey Miscellaneous Investigations Series Map I-943, scale 1:62,500.

Witkind, I.J., and Prostka, H.J., 1980, Geologic map of the southern part of the lower Red Rock Lake quadrangle, Beaverhead and Madison Counties, Montana, and Clark County, Idaho: U.S. Geological Survey Miscellaneous Investigations Series Map I-1216, scale 1:62,500. 